\title{
$\nabla$ Association of Anthropometric Characteristics with Fielding Skill among Male Softball Players
}

\section{IJCRR} \\ Section: Healthcare \\ ISI Impact Factor \\ (2019-20): 1.628 \\ IC Value (2019): 90.81 \\ $\operatorname{SJIF}(2020)=7.893$ \\ (c) (i) (3) \\ Copyright@IJCRR
}

\section{Mandeep Singh', Jaspal Singh ${ }^{2}$}

'Assistant Professor, Department of Physical Education, Doaba College, ]alandhar, Punjab, India; 'Principal, SGGS Khalsa College, Mahilpur, Hoshiarpur, Punjab, India.

\section{ABSTRACT}

Introduction: Objective: The purpose of this study was to ascertain the relationship between anthropometric and body composition characteristics with fielding skills among softball players.

Methods: A total one hundred and fifty male softball players, aged 18-30 years, from the various states and universities of India were selected to participate in the study. All the subjects were assessed for anthropometric characteristics viz. height, body weight, length measurements, circumferences, diameters and skinfolds thicknesses of body parts. Percentage body fat was estimated from the sum of skinfolds was calculated using the standard equations. The Fielding skill test of the players was assessed with the help of the AAHPERD softball skill test battery edited by Dr. Roberta Rikli.

Results: The results of the correlation analysis revealed a significant association of weight $(p=0.045)$ with the fielding skill. The fielding skill was also observed to be significantly associated with upper arm circumference $(p=0.049)$ and bicondylar humerus diameter $(p=0.020)$ among softball players. Among the body composition parameters, only lean body mass ( $p=0.005)$ was observed to be significantly associated with the fielding skill among softball players.

Conclusion: Anthropometric and body composition characteristics should therefore be taken into account during softball talent selection and development, as they tend to be a requirement for future high-level performance in the game.

Key Words: Anthropometric Characteristics, Softball, Performance, Fielding, Percent Body Fat

\section{INTRODUCTION}

The game of softball has many skills such as throwing, fielding, pitching, catching, base-running and hitting. ${ }^{1,2}$ To develop these skills, many factors play a significant role like practice, level of physical activity, techniques, psychological traits, nutrition and other environmental factors. However, a particular body structure and certain genetically conditioned abilities and features are required to achieve top-level performance. Physical and body composition characteristics of elite athletes are different among sports. While selecting athletes for a particular sport, the focus should be on those traits and abilities which have the most significant influence on sports performance, such as anthropometric characteristics and body composition components. ${ }^{3}$ Anthropometric characteristics of an individual player are the most significant factors that contribute to the success of a whole team in the competition. Anthropometry is the science that deals with the measurement of size, weight, proportions and compositions of the human body, as body size and proportions, body composition and physique are vital ingredients of physical performance and fitness. ${ }^{4}$ Anthropometric characteristics of an athlete are important prerequisites for competitive success in any sport. ${ }^{5}$ Indeed, it can be assumed that an athlete's anthropometric characteristics can in some way influence his/ her level of performance, at the same time helping to find a suitable physique for a particular sport. ${ }^{6-8}$ The other factors such as physical training and exercise can improve the performance up to a certain limit that is set up by his genotype. ${ }^{9}$ Many studies have been reported that performance in sports is associated with specific anthropometric measurements, body composition and physique of the sportspersons. ${ }^{7,10,11}$ There have been many more reports on investigations on the association of anthropometric characteristics with physical performance and sports performance. Chen ${ }^{12}$ evaluated the impact of anthropometric characteristics and physical perfor-

\section{Corresponding Author:}

Dr. Jaspal Singh, Principal, SGGS Khalsa College, Mahilpur, Hoshiarpur, Punjab, India.

Ph: 9417032500; Email: jaspal1165@yahoo.com

ISSN: 2231-2196 (Print)

Received: 09.08.2020
ISSN: 0975-5241 (Online)

Revised: 14.10 .2020
Accepted: 13.11 .2021
Published: 16.02 .2021 
mance on the success in the competition and suggested that anthropometric characteristics and physical performance are strongly associated with each other.

Apart from the role of body size, the constitutional makeup of body composition components is also important. Body composition refers to the distribution of muscle and fat in the body. Assessment of anthropometric parameters and body composition, therefore, has an important role in sports and health. Excess body fat besides leading to obesity and disease causation may also hinder performance. ${ }^{13}$ Body composition is an important aspect of fitness ${ }^{14}$ and can be predicted from anthropometric measures ${ }^{4}$. Body composition of athletes is a vital tool to monitor the effects of a training program and to determine optimal competitive body weight and body composition..$^{15}$ It is generally accepted that lower relative body fat is desirable for competitive success in the sports. This is because excessive adipose tissue acts as a dead weight in activities where the body mass must be repeatedly lifted against gravity during locomotion. ${ }^{16,17}$ Higher levels of fat mass slow down the performance and increase the energy requirements of the activity. On the other hand, lean body mass contributes to power generation during high-intensity activity. Several studies also reported that the lean body mass has a better correlation to success in sport (maximum aerobic performance, running time, strength etc) than the percentage body fat. ${ }^{18-20}$ It has been earlier reported that the magnitude and proportion of the active mass are closely linked to various functional variables like e.g. oxygen consumption while at rest and work, cardiac output, circulating blood volume etc. ${ }^{21}$ Studies of body composition in certain sports such as football, weight lifting and shot put indicated that athletes who were lean but heavy because of a well-developed musculature were superior in performance in competitive sports activities. $^{22}$ The aim of the present study, therefore, is to study the relationship of anthropometric characteristics and body composition with the fielding skill among the male softball players.

\section{MATERIALS AND METHODS}

The present study was conducted on 150 male softball players. The male softball players of different universities and states of India were selected to participate in the study. The mean age of the subjects was $21.35 \pm 2.57$ years.

\section{Anthropometry}

Weight of the softball players was assessed with a portable weighing machine to the nearest $0.5 \mathrm{~kg}$. Height and arm and leg length measurements of the softball players were measured with the help of anthropometric rod to the nearest 0.5 cm (HG-72, Nexgen ergonomics, Canada). Flexible steel tape was used to measure the circumferences of body parts of players. The diameters of the body parts of the softball players were assessed with the help of digital sliding calliper. Harpenden skinfold calliper was used to assess the skinfolds thicknesses of body parts of the subjects.

\section{Body Composition}

Different components of body composition viz. percentage body fat, total body fat and lean body mass were calculated from the sum of skinfolds by using the equations of $\operatorname{Siri}^{23}$ and Durnin and Womersley. ${ }^{24}$ The regression equations for the calculation of body density from the sum of skinfold thickness at four sites are as follows:

\begin{tabular}{|l|l|}
\hline 17 to 19 years age group & 20 to 29 years age group \\
\hline Body Density $(\mathrm{gm} / \mathrm{cc})=$ & Body Density $(\mathrm{gm} / \mathrm{cc})=1.1631^{-}$ \\
$1.1620-0.0630(\mathrm{X})$ & $0.0632(\mathrm{X})$ \\
\hline
\end{tabular}

Where $\mathrm{X}=\log$ (biceps+triceps+Subscapular+suprailliac).

Percent Body Fat $=[4.95 /$ body density-4.5] $] \times 100$

Total Body Fat $(\mathrm{kg})=(\%$ body fat $/ 100)$ body mass $(\mathrm{kg})$

Lean Body Mass $(\mathrm{kg})=$ body mass $(\mathrm{kg})$ - total body fat $(\mathrm{kg})$

\section{Fielding Ground Balls Test}

Fielding skill test of the players was assessed as given in the AAHPERD softball skill test battery. ${ }^{25}$ This test item assesses the fielding ground ball ability of the subject. Validity coefficient of correlation has been found to range from 0.60 to 0.85 . The reliability coefficient of correlation ranged from 0.69 to 0.91 from the intra-class test-retest scores. For this test, the area was marked as shown in figure 1. The subject stood behind the restraining line (Point A). A thrower (Point B) stood behind the throwing line and throws six test balls to each subject. Each throw must strike the ground before the 30 -feet line and must stay within the sideline boundaries of the marked area. The throws were sidearm, with sufficient velocity to carry an untouched ball beyond the end line (Point C). Of the six test trials, two balls (in varying order) were thrown directly to the subject, two to the right and two to the left side of the subject. Each ball cleanly fielded in front of the 60 -feet line was count 4 points. A ball counted 2 points when it was stopped, but bubbled. Balls fielded behind the 60 -foot line received one-half the points normally earned. Balls that get past the subject scored no points. The final score was the sum of six trials.

\section{Statistical Analysis}

Statistical analyses for the present study were done with the help of SPSS version 16.0 for windows (SPSS Inc, Chicago, IL, USA). To determine the association between anthropometric and body composition characteristics and fielding skill test among the softball players, Karl Pearson's productmoment coefficient of correlation was applied. Significance levels were set at $\mathrm{p}<0.05$. 


\section{RESULTS}

The correlation analyses of height, weight and body mass index with fielding skill test among the university and national level male softball players are presented in table 1. A significant positive association of weight $(r=0.164, p=0.045)$ with the fielding skill test was reported among the male softball players. The height and body mass index of male softball players did not demonstrate a significant association with the fielding skill test. Table 2 depicts correlation analyses of various length measurements of body parts with the fielding skill test in male softball players. The results of correlation analyses revealed that the length measurements of different body parts viz. total arm, upper arm, lower arm, total leg, upper leg and lower leg lengths did not demonstrate a significant relationship with fielding skill test among the male softball players. The correlation analyses of the various circumferences of body parts with the fielding skill test of the male softball players are presented in table 3. The fielding skill was observed to be significantly associated with upper arm circumference $(r=0.160, p=0.049)$ among the male softball players. The forearm, chest, thigh and calf circumferences showed no significant association with the fielding skill test among the male softball players. The correlation analyses of the diameters of various body parts with the fielding skill test of the male softball players are presented in table 4 . The bicondylar humerus $(\mathrm{r}=0.190, \mathrm{p}=0.020)$ diameter was observed to be significantly associated with fielding skill test in male softball players. However, the biacromial, wrist and bicondylar femur diameters did not demonstrate a significant relationship with fielding skill test among the male softball players. Table 5 shows the correlation analyses of skinfold thicknesses of various parts of the body with the fielding skill test among the male softball players are. There was no significant relationship of the skinfold thicknesses of the body parts viz. biceps, triceps, subscapular, supra-iliac and calf skinfolds with the fielding skill test among the male softball players. The correlation analyses between the various components of body composition and the fielding skill test of the male softball players are depicted in table 6. Lean body mass $(r=0.228, p=0.005)$ was observed to be significantly associated with the fielding skill test in the male softball players. The fielding skill test did not demonstrate a significant association with per cent body fat and total body fat among the male softball players.

\section{DISCUSSION}

Anthropometric characteristics are undoubtedly performance-related factors and high performers can be distinguished from low performers by anthropometric characteristics such as height, weight, circumferences etc. ${ }^{26,27}$ The present study evaluates the anthropometric characteristics of the male university and national level softball players and to ascertain the relation of anthropometric characteristics with fielding skill. The weight of the male softball players was significantly associated with fielding skill. The greater body weight among the male softball players probably leads to higher lean body mass and due to which there will be greater energy output and it will lead to enhanced performance. This might be the reason that the bodyweight showed a significant relationship with fielding performance. These findings confirm with those reported by Mangine et al. ${ }^{28}$ on professional baseball players in which a relationship between fielding performance and body weight was observed and body weight was reported as the best predictor for fielding performance among corner infielders and middle infielders. A player has to move around a lot while collecting the ball during fielding in the game of softball and requires a greater reach. The upper arm circumference and bicondylar humerus diameter of the male softball players showed a positive significant relationship with fielding skill. The high arm circumferences is an advantageous factor in sports as it can be considered an indicator of higher muscle mass cross-sectional area and consequently of higher power and force output for these segments. ${ }^{29}$ The higher diameters of body parts may indicate the better growth and development of the softball players. These characteristics might be helpful for softball players while moving around during fielding in softball.

The skinfold thicknesses and per cent body fat did not demonstrate a significant association with fielding skill among both male softball players. The greater skinfold thicknesses and higher body fat percentage may have a detrimental effect on fielding performance of the softball players as these factors may obstruct the players while moving around and bending forward to collect the ball during the fielding. These findings are in line with those reported on under- 15 softball players studied by Rao and Kumar. ${ }^{30}$ The lean body mass demonstrated a significant correlation with fielding skill among male softball players. These findings are in agreement with those reported by Mangine et al. ${ }^{28}$ on professional baseball players in which a relationship between fielding performance and lean body mass was observed. Many studies in literature reported that greater the lean body mass, the greater will be the energy output and higher will be the cardiorespiratory fitness which leads to enhanced performance level. ${ }^{18-20,31,32}$. It has been earlier reported that the magnitude and proportion of the active mass are closely linked to various functional variables like e.g. oxygen consumption while at rest and work, cardiac output and circulating blood vol$u^{21}{ }^{21}$. The more muscular make-up of the players would be advantageous for performance among softball players. ${ }^{27}$ These findings confirm with those reported by Hoffman et al. ${ }^{33}$ on the minor and major baseball league players. In conclusion, as whole many anthropometric characteristics and body composition components demonstrated a positive significant association with fielding skill among softball players. 
Hence the anthropometric characteristics and body composition components play a vital role in performance among softball players.

\section{CONCLUSION}

Anthropometric characteristics such as weight, upper arm circumference, bicondylar humerus diameter and lean body mass were the main factor correlating with fielding skill in male softball players. These characteristics should therefore be taken into account by the coaches/trainers during softball talent selection, as they tend to be a requirement for future high-level performance in the game.

\section{ACKNOWLEDGEMENT}

Authors acknowledge the immense help received from the players and coaches during the data collection. Authors also acknowledge the help received from scholars whose articles are cited and included in references to this manuscript. The authors are also grateful to authors/editors/publishers of all those articles, journals and books from where the literature for this article has been reviewed and discussed.

Conflict of Interest: Authors declare there is no conflict of interest.

\section{Funding: Nil}

\section{REFERENCES}

1. American Academy of Pediatrics. Policy statement baseball and softball. Paediatrics. 2012; 129(3):842-856.

2. Craig SB, Craig S, Johnson K. The softball handbook. Leisure Press. 1985; 16-22.

3. Markoviæ G, Durakoviæ MM, Trnini S. Fitness profile of elite Croatian female Taekwondo athletes. Collegium Antropologicum 2005;29(1):93-99.

4. Maud PJ, Foster C. Physiological assessment of human fitness. Champaign, Illinois. Human Kinetics. 1995.

5. Gualdi RE, Zaccagni L. Somatotype, role and performance in an elite volleyball player. J Sports Med Phys Fitness 2001;41:256262.

6. Carter JEL, Heath BH. Somatotyping-development and applications, Cambridge University Press, New York; United States. 1990.

7. Duncan MJ, Woodfield L, al-Nakeeb Y. Anthropometric and physiological characteristics of junior elite volleyball players. Br J Sports Med 2006;40:649-651.

8. Rienzi E, Reilly T, Malkin C. Investigation of anthropometric and work-rate profiles of Rugby Sevens players. J Sports Med Phys Fitness 1999;39:160-164.

9. Bouchard C, Malina RM. Genetics of physiological fitness and motor performance. Exerc Sports Sci Rev 1983;11:330-339.

10. Bayios IA, Bergeles NK, Apostolidis NG, Noutsos KS, Koskolou MD. Anthropometric, body composition and somatotype differences of Greek elite female basketball, volleyball and handball players. J Sports Med Phys Fitness 2006; 46:271-280.
11. Hakkinen K. Changes in physical fitness profile in female volleyball players during the competitive season. J Sports Med Phys Fitness 1993; 33:223-232.

12. Chen S. Some differences in non-technique factor between Asian and Euro-American female volleyball player. J China Sport Sci Tech 1999;35.

13. Vipene JB, Victor OA. Anthropometric study of body composition variables in selected male and female athletes in rivers state, Nigeria. Asian J Soc Sci Humanities 2013; 2(4):281-287.

14. Reilly T, Sechei N, Snell P, Williams C. Physiology of sports. London: E \& FN Spon, 1990.

15. Prior BM, Modlesky CM, Evans EM, Sloniger MA, Saunders MJ, Lewis RD, Cureton KH. Muscularity and the density of the fat-free mass in athletes. J Appl Physiol 2001; 90:1523-1531.

16. Reilly T. Fitness assessment. In: Reilly T, editor. Science and Soccer. London: E \& F Spon; 1996; pp.25-50.

17. Mala L, Maly T, Zahalka F, Bunc V, Kaplan A. Jebavy R, Tuma M. Body composition of elite female players in five different sports games. J Human Kinet 2015; 45:207-215.

18. Bale P. Anthropometric, body composition and performance variables of young elite female basketball players. J Sports Med Phys Fitness 1991; 31:173-177.

19. Wilmore JH, Haskell WL. Body composition and endurance capacity of professional football players. J Appl Physiol 1972; 33:564-567.

20. Mathur DN, Salokun SO. Body composition of successful Nigerian female athletes. J Sports Med 1985; 25:27-21.

21. Parizkova J. Body fat and physical fitness. Body composition and lipid metabolism in different regimes of physical activity. Hague: Martinus Nijhooff, 1977.

22. Bullen BA. Overweight: In Encyclopedia of sports Sciences and Medicine. The Macmillan Company New York, 1971.

23. Siri WE. The gross composition of the body. Adv Biol Med Physc 1956; 4:256-280.

24. Durnin JVGA, Womersley J. Body fat assessed from total body density and its estimation from skinfold thickness measurements of 481 men and women aged from 16-72 years. Br J Nutr 1974; 32:77-97.

25. AAHPERD (American Alliance for Health, Physical Education, Recreation and Dance). Softball skills test manual for boys and girls. Roberta Rikli (Ed.), AAHPER, Reston, VA, USA, 1991.

26. Kaloupsis S, Bogdanis GC, Dimakopoulou E, Maridaki M. Anthropometric characteristics and somatotype of young Greek rowers. Biol Sport 2008; 25(1):57-69.

27. Singh S, Singh M, Rathi B. Kinanthropometric and performance characteristics of elite and non-elite female softball players. J Sports Med Phys Fitness 2013;53(6):628-634.

28. Mangine GT, Hoffman JR, Vazquez J, Pichardo N, Fragala MS, Stout JR. Predictors of fielding performance in professional baseball players. Int J Sports Physiol Perfor 2013; 8(5):510-516.

29. Wilmore JH, Costill DL. Physiology of Sport and Exercise. Champaign, IL: Human Kinetics, 1999.

30. Rao SK, Kumar PPS. The relationship between selected physiological parameters variables with playing ability of softball players. Int J Engi Res Sports Sci 2015; 2(4):1-4.

31. Bandyopadhyay A, Chatterjee S. Body composition, morphological characteristics and their relationship with cardiorespiratory fitness, Ergonomics SA. 2003; 15:19-27.

32. Chatterjee S, Chatterjee P, Bandyopadhyay A. Cardiorespiratory fitness of obese boys. Indian J Physiol Pharmacol 2005; 49:353357.

33. Hoffman JR, Vazquez J, Pichardo N, Tenenbaum G. Anthropometric and performance comparisons in professional baseball players. J Strength Condit Res 2009;23(8):2173-2178. 


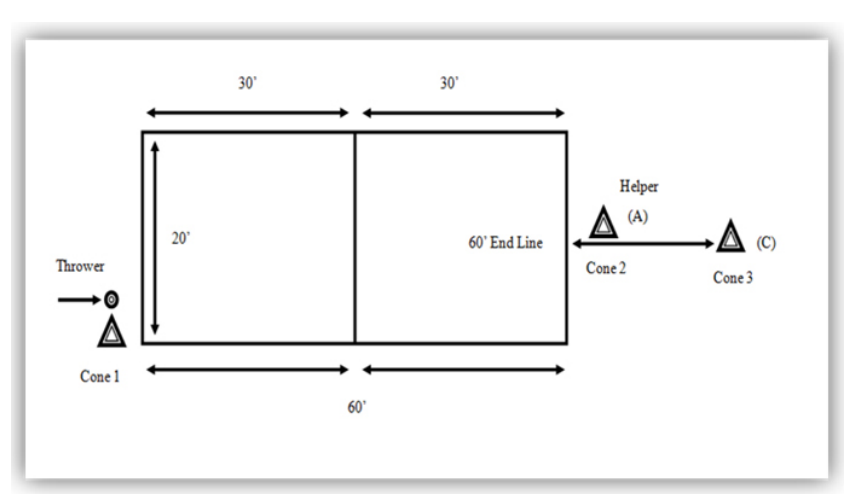

Figure 1: Field marking for fielding ground balls test.

Table 1: Relationship of height, weight and body mass index with the fielding skill test in male softball players

\begin{tabular}{lccc} 
Variables & N & $\begin{array}{c}\text { Pearson Cor- } \\
\text { relation Coeffi- } \\
\text { cient }(\mathrm{r})\end{array}$ & $\begin{array}{c}\text { Sig. } \\
\text { (2-tailed) }\end{array}$ \\
\hline Height $(\mathrm{cm})$ & 150 & 0.075 & 0.361 \\
Weight $(\mathrm{kg})$ & 150 & 0.164 & $0.045^{*}$ \\
$\begin{array}{l}\text { Body Mass Index } \\
\left(\mathrm{kg} / \mathrm{m}^{2}\right)\end{array}$ & 150 & 0.126 & 0.123 \\
\hline
\end{tabular}

* Indicates $\mathrm{p}<0.05$

Table 2: Relationship of the length measurements of body parts with the fielding skill test in male softball players

\begin{tabular}{lccc} 
Variables & N & $\begin{array}{c}\text { Pearson } \\
\text { Correlation } \\
\text { Coefficient } \\
(\mathbf{r})\end{array}$ & $\begin{array}{c}\text { Sig. } \\
\text { (2-tailed) }\end{array}$ \\
\hline Total Arm Length $(\mathrm{cm})$ & 150 & 0.119 & 0.148 \\
Upper Arm Length $(\mathrm{cm})$ & 150 & 0.119 & 0.146 \\
Lower Arm Length $(\mathrm{cm})$ & 150 & 0.067 & 0.418 \\
Total Leg Length $(\mathrm{cm})$ & 150 & -0.040 & 0.623 \\
Upper Leg Length $(\mathrm{cm})$ & 150 & -0.028 & 0.734 \\
Lower Leg Length $(\mathrm{cm})$ & 150 & -0.047 & 0.569 \\
\hline
\end{tabular}

Table 3: Relationship of the circumferences of the body parts with the fielding skill test in male softball players

$\begin{array}{lccc}\text { Variables } & \text { N } & \begin{array}{c}\text { Pearson } \\ \text { Correlation } \\ \text { Coefficient } \\ (\mathbf{r})\end{array} & \begin{array}{c}\text { Sig. } \\ \text { (2-tailed) }\end{array} \\ \begin{array}{l}\text { Upper Arm Circumference } \\ (\mathrm{cm})\end{array} & 150 & 0.160 & 0.049^{*} \\ \text { Forearm Circumference }(\mathrm{cm}) & 150 & 0.130 & 0.113\end{array}$

Table 3: (Continued)

\begin{tabular}{lccc} 
Variables & N & $\begin{array}{c}\text { Pearson } \\
\text { Correlation } \\
\text { Coefficient } \\
(\mathrm{r})\end{array}$ & $\begin{array}{c}\text { Sig. } \\
\text { (2-tailed) }\end{array}$ \\
\hline Chest Circumference $(\mathrm{cm})$ & 150 & 0.135 & 0.098 \\
Thigh Circumference $(\mathrm{cm})$ & 150 & -0.008 & 0.925 \\
Calf Circumference $(\mathrm{cm})$ & 150 & 0.104 & 0.206 \\
\hline
\end{tabular}

* Indicates $\mathrm{p}<0.05$

Table 4: Relationship of the diameters of the body parts with the fielding skill test in male softball players

\begin{tabular}{lccc} 
Variables & $\mathbf{N}$ & $\begin{array}{c}\text { Pearson } \\
\text { Correlation } \\
\text { Coefficient } \\
(\mathbf{r})\end{array}$ & Sig. (2-tailed) \\
\hline $\begin{array}{l}\text { Biacromial Diameter } \\
(\mathrm{cm})\end{array}$ & 150 & 0.156 & 0.056 \\
$\begin{array}{l}\text { Bicondylar Humerus } \\
\text { Diameter (cm) }\end{array}$ & 150 & 0.190 & $0.020^{*}$ \\
$\begin{array}{l}\text { Wrist Diameter (cm) } \\
\text { Bicondylar Femur }\end{array}$ & 150 & -0.032 & 0.699 \\
Diameter (cm) & 150 & 0.068 & 0.408 \\
\hline
\end{tabular}

* Indicates $\mathrm{p}<0.05$

Table 5: Relationship of the skinfold thicknesses of the body parts with the fielding skill test in male softball players

\begin{tabular}{lccc} 
Variables & N & $\begin{array}{c}\text { Pearson Correla- } \\
\text { tion Coefficient } \\
(\mathbf{r})\end{array}$ & \\
\hline Biceps $(\mathrm{mm})$ & 150 & -0.101 & 0.218 \\
Triceps $(\mathrm{mm})$ & 150 & -0.028 & 0.735 \\
Subscapular $(\mathrm{mm})$ & 150 & 0.013 & 0.872 \\
Supra-iliac (mm) & 150 & -0.081 & 0.326 \\
Calf $(\mathrm{mm})$ & 150 & 0.046 & 0.572 \\
\hline
\end{tabular}

Table 6: Relationship of the components of body composition with the fielding skill test in male softball players

\begin{tabular}{lccc} 
Variables & N & $\begin{array}{c}\text { Pearson Cor- } \\
\text { relation Coef- } \\
\text { ficient (r) }\end{array}$ & Sig. (2-tailed) \\
\hline Percent Body Fat (\%) & 150 & -0.073 & 0.572 \\
Total Body Fat (kg) & 150 & 0.020 & 0.804 \\
Lean Body Mass (kg) & 150 & 0.228 & $0.005^{*}$ \\
\hline * Indicates p<0.05 & & &
\end{tabular}

